\title{
Zhengdong New District Smart Government Application System Construction and Its Development Strategy Research
}

\author{
Bing $\mathrm{Li}^{*}$, Xianghua Xing, Hua Xuan and Xueyuan Wang \\ School of Management Engineering, Zhengzhou University, Zhengzhou, China \\ *Corresponding author: 1bing@zzu.edu.cn
}

\begin{abstract}
Smart government is the advanced stage of e-government development, whose essence is the fusion of Internet, Internet of things, cloud computing, big data and other high and new technology and e-government, to achieve the efficient management of all kinds of information resources and make the government services more transparent, scientific and wisdom. Based on the introduce, basic principle and construct meaning, application system construction, main problems and developing countermeasures and other aspects of smart government to make a comprehensive analysis in the construction of Zhengdong new district smart government, then advise the government departments to speed up the transformation of government management functions and social service mode to integrate the business processes, and promote the construction of service-oriented and smart-oriented government actively.
\end{abstract}

Keywords. Smart government, application system, problem analysis, development countermeasures.

\section{Introduce}

As the Internet, the Internet of things ( IOT), the service-oriented architecture (SOA),cloud computing, big data and other high and new technology applied widely, in order to speed up the transformation of the mode of government management and service and improve government scientific decision-making ability as soon as possible, and build smart and service-oriented government quickly, the Chinese government has issued "National new urbanization plan (2014-2020)"and "Guiding Opinions on Promoting the Healthy Development of the smart city", clearly put forward to accelerate the construction of the smart city.

Smart government affairs is the important constituent parts in the construction process of the smart urban and development foundation, provide important support for other areas of intelligence applications, and is also the advanced stage of e-government, whose essence is the fusion of Internet, IOT, SOA, cloud computing, big data and other high and new technology and e-government [1], to achieve the efficient management of all kinds of information resources and has become an important way to change the functions of management and social services, and integrate business process. Smart government can provide convenient and efficient service for the general public [2], also can provide scientific decision-making basis for government departments to accelerate the construction of smart and service-oriented government.

Smart government mainly has perception, collaborative, intelligence and service-oriented characteristics. Among which, the perception refers to the changes in the data sources, collaborative refers to the use of high-tech to break the boundaries between government departments and change collaboration efficiency, intelligence is the change in the use of data, servitization refers to the transformation of government departments and management of service delivery. The 
perception, collaborative and intelligence is the basis of servitization, the servitization is the ultimate goal of perception, collaborative and intelligence.

\section{Basic principle and construct meaning}

\subsection{Basic principle}

Based on "Top-level design of smart city of Zhengdong new district" and "Eastern wisdom Thirteen Five Development Plan", combined with the building requirements of smart government of national and provincial government, identify the major purposes of building smart government at Zhengdong new district is in order to improve the management of government departments and public service capabilities, accelerate the transformation of the city' upgrading, and further enhance the convenience and comfort of people's lives, the overall design of Zhengdong new district smart government should follow the following principles:

(1) Overall planning and intensive construction. Smart government is the important constituent parts and development foundation in the construct process of the smart city, its planning and construction need to be a good cohesion with the overall urban planning wisdom [3]. In the specific planning and design, need to focus on the overall situation, implement the national and provincial smart government's framework relevant standards, with smart eastern district's the actual construction of " $3+1+1$ ", to avoid the relevant departments' fragmentation, dispersion and duplication of investment in construction and other phenomena.

(2) Integrate resources and share information. Based on public information resources' sharing, integration and business collaboration, implement disclosure the government information and government business collaboration system actively, to achieve real-time exchange of information interconnection and government business systems, set up covering the entire area of the cloud data center of smart government, benefit maximize information resources.

(3) Uniform standards to ensure safety. Depth study the policy documents' information and standards of national and provincial government how to construct smart government, focusing on the regulatory system, security system and operation and maintenance management system's construction of smart government[3], realize the unity of the command, the coordination and the maintenance within the region and smart government become the leading and demonstrating building in Zhengzhou.

(4) Moderate prospective and leapfrog development. The rapid development of high-tech, government institutional restructuring mechanism deepening, the construction of smart government should be based on the current situation, but also with a modest-looking, to meet the needs of government departments managed services model and high-tech development to ensure sustainable and leaping development of smart government.

\subsection{Construct meaning}

Implementing the new smart city of Xi Jinping General Secretary's important speech, reflecting the people-oriented and service-oriented smart governing philosophy, the main significance of constrict Zhengdong new district smart government as following:

(1) Solve the "information island" problem effectively. By using high-tech applications and constructing standard system, security system and operation management system of smart government, can help resolve the "islands of information" during the administrative examination [4], and can help achieve the information resources' integrating and sharing.

(2) Reduce costs and optimize resources. With sharing and integrating basic information resource, introducing and using a series of advanced high-tech tools and services means to accelerate the construction of government cloud data center, to achieve effective interconnection of various information data, can not only save equipment and labor costs, and it can also integrate and optimize resources effectively. 
(3) Improve the efficiency of government departments effectively. The government cloud data center can address interoperability of data resources between Zhengdong new district offices, can promote the integration and sharing and can also promote the good synergy between the services, can help government departments to achieve "one-stop" office functions, in order to promote the government's work efficiency.

(4) Effectively assist scientific decision-making. The smart government can help leaders understand the dynamics of city management, economic, social development and other information, can provide early warning and predictive analysis and other technical support for the leaderships' scientific decision-making, to enhance the region's management and the overall effectiveness of services business.

\section{Smart government application system}

Within the scope of public administration, all kinds of complex factors, it is necessary to consider the amount and quality of data and efficiency and economy of data analysis, but also think about new synthetic methods and analytical data, in order to enables data to realize its own value. Based on this consideration, when construct the overall framework of Zhengdong new districts mart government applications system should be based on the smart government unified standards system, security system and operation management system as the basis, take the construction of the cloud computing center that provides hardware and software environment in "Eastern wisdom" project planning as a support, Mainly includes the following content:

\subsection{Cloud data center of smart government}

Smart government cloud data center is an important part of smart government's construction process, is also the bottom support of the city data, is also highly resource information sharing breakthrough, can provide foundation for information sharing and integration between government departments and collaboration between services business, therefore we must accelerate the use of high-tech to establish smart government cloud data centers including population database, corporate libraries, library and other basic spatial information database[5]. Among them, the population information repository can help government manage the basic information about population; Corporate library is a quality inspection organization code based on indexes, take business registration and tax registration as supplemented index forming the enterprise underlying database, to achieve information sharing and dynamic updates of corporate units; Spatial geographic information database based on the electronic map, mainly including basic and thematic data, such as administrative divisions, urban ecological environment, scientific research institutes.

\section{2 "Five list one single network" information system}

From the "Five list one single network" to start optimize and improve government service management mechanism, which is a basic requirement to construct service-oriented and smart government, is also an important measure to improve public service satisfaction and speed up building a harmonious society. "Five list one single network" refers to the list of responsibilities of government, the list of administrative examination and approval matters, the list of industrial clustering enterprise investment project management, the list of administrative fees and charges, the list of government investment funds, the establishment of the region's unified government service information network [6] . "Five list one single network" smart government system mainly includes office project approval platform, project approval service platform, integrated query platform for project approval, project approval statistical analysis platform.

\subsection{The city's comprehensive management platform of smart eastern district}

"The city's comprehensive management platform of smart eastern district" takes the scientific intelligent city management as the goal, on the basis of urban grid management application system, the construction of the city's comprehensive management platform is in order to promote urban management components to solve things standardization and 
participation of the whole idea implemented. On the basis of the existing The city's comprehensive management platform of smart eastern district's works and extend other units of video access points, to improve collaboration and coordination between the services and the lateral sectors and establish and improve urban management information base, and design and build the system by using disposal cases, GIS maps, statistical analysis, performance evaluation, system management, intelligent collection terminals and other standard modules [7].

\subsection{Economic operation information platform of smart eastern district}

"Economic operation information platform of smart eastern district" takes the tax-related information private network as the carrier, based on the software platform to set up a "government-led, sector assistance and social participation" as the main content of socialization comprehensive management tax running system [8]. The system is mainly based on the digital three-dimensional geographic information data and mobile private network, can full use of information technology's advantage, and set up information sharing platform for tax management, strengthen the relevant government departments of tax-related information resources' integration, in order to fully grasp the scale, distribution, composition and changes of tax sources, plug the loopholes in collection to prevent the loss of tax revenue, mainly including sources of revenue ledger management, tax source analysis, coordination department, tax co-grid, building economic and other sources module [9].

\section{Main problems}

Zhengdong new district smart government can provide an effective way for the government comprehensive upgrade of public administration and public services, can help improve the government's governance capabilities, also is a self-flagellation for the government. But the building of smart government is an complex system engineering, there is a lot of uncertainty related to the Internet, IOT, SOA and other high-tech, so Zhengdong new district government authorities should make sufficient attention to smart government.

\subsection{Information resources' quality and safety should be improved and guaranteed}

Government information resource database has a lot of personal information, the quality and safety of information resources is the prerequisites of smart government healthy development. Professionals of internet, IOT, SOA, cloud computing, big data and other high-tech aspects are relatively scarce, resulting in the deviation of information resource quality and increase risk of safety [10]. Information security issues of Zhengdong new district smart government is mainly reflected on information security technology, information security management, information security laws and regulations, information security awareness [11].

\subsection{Responsibilities inventory systems needs to be deepened}

With the reform and establishment of laws and regulations and the adjustment of institutions and functions, the published list needs dynamic updates in a timely manner. Public service matters that are closely related to mass production and life is incomplete, should according to the laws and regulations conduct further sort to approve, in order to reduce handling process, link and time limits and improve the standard.

\subsection{Government affairs service system needs to be improved}

The city's administrative examination and approval service platform is incomplete relatively, still need to strengthen top-level design, and actively implemented. The existing functions of the position and reform requires of offices service center can't match exactly, matters entered service hall are also inconsistent completely, and many convenient service centers' hardware facilities, services function, construction and other mechanisms have to be further standardized. 


\subsection{Smart government management system needs to be strengthened}

The building of Zhengdong new district smart government platform lacks strong leadership, planning and operation and maintenance team, the authorities lack effective monitoring and support in the planning, management and implementation of the project, when coordinate the constructing work of Zhengdong new district smart city, the department and daily management is always inadequate.

\section{Developing countermeasures}

\subsection{Improve the data quality and information security system}

(1) Establish information security system. Clear scientific information security legal protection philosophy, strengthen information security laws and regulations, strengthen information security ahead of legal efficiency, based on four levels that physical layer security, internet layer security, security system layer and application layer security, then establish security risk assessment mechanism and comprehensive security audit system of smart government.

(2) Strengthen personnel security system. Set up Internet, IOT, big data and other high-tech programs in Longzihu university campus, to train high-level, highly skilled person for the wisdom of government. Explore service policy of talents, simplify the process of introduction of talents, make full use of scientific research institutions and other platforms to absorb professionals of the smart government affairs.

(3) Increase capital investment. Strengthen the integrated management of special funds in the construct of informational government departments, to ensure the construction of information technology applications of various departments. Accelerate to innovate investment and financing and operating model in the construct of smart government, help Zhengdong new district smart government form a good situation comprehensively.

(4) Improve the system of accountability. Based on the collection and classification, statistical analysis, application management and other links of data, to formulate behavior standards and secrecy system, and formulate identification and punishment system for the abuse, private and generic of data [12].

\subsection{Deepening the Reform of the "Five list one single network"}

(1) Speed up administrative responsibilities matters into network. Formulate inspect together, judge and estimate, evaluate performance and other supporting mechanisms actively, for the operation of all levels of inventory for dynamic monitoring, tracking judged, performance evaluation. Start to handle case and enforce law online and trace the whole actively, implement publicity system of the enforcement of administrative law, explore administrative expropriation, compulsory administrative matters, and other types of administrative powers and responsibilities into network, realize all administrative powers and responsibilities matters can be running in the network.

(2) Speed up administrative responsibilities matters star-management. Strengthen the analysis of accountability matters, and combine with counseling, complaints and suggestions of the public, to simplify the optimization of processes online. Use big data means to sort out administrative powers and responsibilities matters, to achieve star-management of administrative accountability matters as soon as possible.

(3) Deepen the sharing of information resource on administrative service network. Continue to promote the "Internet + government services", built and apply data sources service platform of Zhengdong new district smart government, and improve the resident population information database, corporate database and geospatial information repository database and other basic database.

(4) Continue to deepen the preparation of inventory systems. Clear the running processes and responsibilities of every job of each matter's all aspects, make measures on how to control risk of integrity, to promote the implementation of administrative accountability matters of personal responsibility, and to promote the lists' implementation. 


\subsection{Improvement smart government affairs service system}

Specification the service functions, operation mechanism, personnel management and other respects of the two governments that district and township (office), unify the name of all government service center as soon as possible, so as to make a good match between the institutional functions and tasks. Accelerate the construction of convenient service centers covering the whole township (office), to provide basic security services for three linkage of Zhengdong new district smart government to provide basic security services three linkages.

\subsection{Strengthen smart government affairs management mechanism}

Clear construct leading group mechanism of smart government to promote the comprehensive building work of smart government. Establish an independent operation team to participate in projects all the time as soon as possible, to enhance the achievements of the operation and maintenance work in the constructing of smart government, to ensure the healthy and sustainable development of the smart government. Establish professional institutions to strengthen the daily management work of smart government, coordinate the construction work of Zhengdong new district smart government with Zhengzhou city and other relevant departments, clear the responsibility, mission and assess goals of relevant departments.

\section{Conclusions}

In summary, smart government is an important component and developing foundation of smart city, is also an more advanced stage of e-government, has become an important way for government departments to change management functions and integrate business processes and change the way of social services in the information age. Smart government let government departments have a more detailed and scientific management of the society, also have great significance in achieving a comprehensive well-off society and promoting the modernization of social governance and building a harmonious society.

\section{Acknowledgements}

This research is supported by the Ministry of Education of Humanities and Social Science Project (Grant no. 15YJC630148).

\section{References}

1. Zhang XH, Deng XF. The Overall Architecture Design Ideas and Implementation Path of Nanjing Smart Government. E-Government, 2013, (9): 103-109.

2. Xu XL, Zhu GW. Smart Government: The Life Path of Electronic Information Society Governance. Journal of Dialectics of Nature, 2012, (34):95-100.

3. Li CM. Construction of Smart Government in the Eyes of Modern Management. Socialism Studies, 2014, (4):81-88.

4. Gu SZ, Yang JW, Liu JR. Current Problems and Measures in the Construction of Smart City in Our Country. China Soft Science, 2013, (1): 6-12.

5. Napitupulu, D. The critical success factors study for e-Government implementation. Int. J. Comput, 2014, 89 (16), $23-32$.

6. Po-Ling Sun, Cheng-Yuan Ku. An implementation framework for E-Government 2.0.Telematics and Informatics, 2015, 32(3):504-520.

7. Hui Zhang, Jianying Xiao. Diffusion of e-government: A literature review and directions for future directions [J]. Government Information Quarterly, 2014, 31(4):631-636. 
8. Song G, Meng QG. Government2.0: Government Innovation in the Eyes of Innovation 2.0. E-Government,2012, $(2-3): 53-61$.

9. Agus Prahono, Elidjen. Evaluating the Role e-Government on Public Administration Reform: Case of Official City Government Websites in Indonesia. ScienceDirect, 2015, 59(3): 27-33.

10. Mohammad Sarrayrih, B. Sriram. Major challenges in developing a successful e-government: A review on the Sultanate of Oman[J]. Journal of King Saud University- Computer and Information Sciences, 2015, 27(2):230-235.

11. Li Y. Informational Security Strengthen and Impact Analysis in the Construction of Smart City. Library and Information Service. 2012, 56(6):20-24.

12. Li DR, Yao Y, Shao ZF. Smart City in Big Dat. Geomatics and Information Science of Wuhan University. 2014, 39(6):631-640. 